Volume 6, Issue 3, July 2021, pp. 158 - 173

DOI: $10.23917 /$ jramathedu.v6i3.13784

p-ISSN: 2503-3697, e-ISSN: 2541-2590

\title{
The mediating effect of students' attitude to student career aspiration and mathematics achievement
}

\author{
Quiliano Jr Gonzales Oracion ${ }^{*}$, Ivy Lyt Sumugat Abina² \\ ${ }^{1}$ Senior High School Department, San Pedro College, Philippines \\ ${ }^{2}$ College of Education, University of Southeastern Philippines, Philippines \\ *Corresponding author: quilliano oracionjr@spcdavao.edu.ph
}

\begin{tabular}{l} 
ARICLE INFO \\
\hline Article history: \\
Received: 26 February 2021 \\
Revised: 6 May 2021 \\
Accepted: 11 May 2021 \\
Published online: 29 June \\
2021 \\
Published regularly: July 2021
\end{tabular}

Published regularly: July 2021

Keywords:

Attitudes, aspiration towards learning, academic achievement, mediating effect

\section{ABSTRACT}

Mathematics low achievement has undeniably been found in both national examinations and international assessments. An educator needs to be aware and determine the factors in students' achievement. However, there were no observable studies focusing on the mediating effect of students' attitudes toward career aspiration and academic achievement. With this, it aims to determine the mediating effect of students' attitudes on students' career aspirations and academic achievement in learning Mathematics in a higher educational institution in the Davao Region. The researcher utilized sets of adopted and selfmade test questionnaires to gather data from the 199 respondents. In analyzing the data, the researcher performed descriptive statistics, Pearson Product Moment Correlation Coefficient, and Regression Analysis as statistical tools. These analyses indicated that students have a high level of career aspiration, a satisfactory level of academic achievement, an average level of attitude towards mathematics, and an insignificant relationship between students' career aspirations and academic achievement. The relationship between the student's attitude and career aspiration is significant. The latter is the only relationship that is significant among all steps, and thus full and partial mediation analysis will not be warranted. Based on the findings, the students must be responsible for helping themselves to make an efficient move in developing their aspiration to have a considerable positive attitude in learning mathematics.

(C) 2021 Universitas Muhammadiyah Surakarta

\section{Introduction}

In every school from kindergarten to college level, mathematics has been a part of the curriculum. We encounter math in our daily lives, yet, in the classroom, students tend to close up their minds to the idea that mathematics is a difficult subject (Langoban, 2020). Throughout the world, mathematics is one of the essential and exciting subjects (Ziegler \& Loos, 2017). As a fundamental learning course, mathematics can be integrated into various fields such as engineering, social sciences, arts, and even the medical field (National Research Council, 2013). Moreover, it plays an essential role in our lives that is essential to determine one's future success and acceptance into college and universities (Gravemeijer, Stephan, Julie, Lin, \& Ohtani, 2017). Although mathematics is indispensable, the difficulty of 
learning the subject is observable. Mathematics achievement remains to be a problem throughout the world. For instance, Program for International Assessment (PISA) 2018 revealed a disappointing trend in mathematics results since most countries revealed a disappointing trend that the scores did not meet the PISA technical standards (Schleicher, $\underline{2019}$ ).

Recent research in England has reaffirmed the relevance of interest towards studying and working in mathematics, together with further factors including the personal value of mathematics to students' identities, current confidence for future attainment, and parental influence(Archer, Dawson, DeWitt, Seakins, \& Wong, 2015; Mujtaba, Sheldrake, Reiss, \& Simon, 2018). Fundamentally, various aspects of students' lives, such as their parents' beliefs (DeWitt et al., 2011) and classroom experiences (Wang, 2012), may influence their attitudes, which may then primarily influence their aspirations-also believing mathematics as an essential or relevant subject which can assist them in their future career (Yara, 2009). Furthermore, a student who has entered the classroom with the right attitude, has the eagerness to learn, and participates makes the lesson easier to learn. Boe and Henriksen ( $\underline{2015}$ ) and Regan and DeWitt ( $\underline{2015}$ ) pointed out that students' attitudes are especially relevant to their career aspirations. They give emphasis on the students' aspiration or interest is related to their attitudes knowing that mathematics led to a variety of benefits such as developing their quantitative skills and boost their confidence in relation to the subject.

Moreover, with the help of students' aspirations, Japan's average score for the Third International Mathematics and Science Study (TIMMS) is 605, which is above the average score (Leedy \& Ormrod, 2010). On the other hand, the mathematics performance of other countriessuch as Malaysia and Indonesia were falling behind in TIMMS due to a lack of opportunity in developing their higher-order thinks skills (HOTS) and lack of support of the curriculum in honing students' aspiration (Mullis, Martin, Goh, \& Cotter, 2016). AbuHilal (2000) and Poudel and Maharjan (2017) stated that students with high career aspirations tend to have higher achievement than those with low career aspirations. However, it is in contrast with some studies showing that there was no relationship between the level of aspiration and students' achievement (Udoukpong, Emah, \& Umoren, 2012; Dwivedi, 2012).

In Kenya, the results of the study by Mutai (2011) stated that poor performance in mathematics examination is a result of sparse learning of the subject. The formed attitudes and fewer hopes towards the subject by the students are the main reasons for their poor performance (Ndirangu, Nyagah \& Kimani, 2017). However, it was evident that students who have a positive attitude and are goal-oriented in learning mathematics performed well in the class (Ballajado-Tan, 2014).

Low performance in mathematics is also an obvious problem in the Philippines. Based on the National Achievement Test (NAT) result for SY 2012-2013, students were poor in this subject with an overall Mean Percentage Score (MPS) of 46.73, which did not reach the 75\% standard level (Dela Cruz, 2017). The sparse performance of the students was due to the lack of equipment, materials, and students' attitudes towards learning the subject contributed to the national examination's sparse performance (The Manila Times, 2014; Tudy, 2014).

The problem of low performance in Mathematics is also evident in Region XI or Davao region. Based on the PISA 2018 average scores in mathematical literacy, the Davao region achieved an average score lower than the national average of 353 points, which falls below level 1 of the proficiency scale of mathematical literacy set by the PISA. Also, based on the results, it was interpreted that students are very low performers (Schleicher, 2019). In 
connection to the result from PISA 2018, the Department of Education (DepEd) conducted remedial or advancement classes during summer but limited to some students who failed in any learning area (DepEd Order NO. 013, s. 2018). Moreover, a particular school in Davao city had shown a below-average mathematical learning ability (Agcopra, 2009), which has a similar case to the school where the researcher is associated. The decline of students' mathematical ability motivated the researcher to dwell on this area.

Furthermore, with the consistent decline in mathematics performance, the Philippines has been rated poorly in terms of the quality of mathematics education (Nicolas \& Emata, 2018). At the same time, students are very low performers in terms of mathematical literacy set by PISA (Schleicher, 2019). On the other hand, the Department of Education together with the Department of Science and Technology (DOST) signed the Capacity Building Program in Science and Mathematics Education. The program is envisioned to help the teachers in the delivery of quality, relevant, and liberating primary education for all (DepEd, 2018).

In addition, this study is anchored in the following theories: The Theory of Planned Behavior by Ajzen (2012) and Multicomponent Model of Attitude (Eagly \& Chaiken, 1993). The theory of planned behavior is anchored by the famous criticism by Ajzen (1991) in which every student has the power to make their own choices or decisions in life; thus, teachers and parents will be the more knowledgeable others to make those choices be complete and guide them to the right path. These indicate how students are willing to do their best or how much effort they are planning to exert in learning a particular subject that inspires them for their future. With this, aspiration and coping are traits that are essential in learning mathematics.

On the other hand, the Multicomponent Model of Attitude was influenced by three components. They are cognitive (beliefs, thoughts, attributes), affective (feelings, emotions), and behavioral information (past events, experiences) (Maio, Haddock, \& Verplanken, 2018). This theory supports the idea that students' attitude influences the academic achievement of the students. Students' academic achievement or performance is not solely affected by innate characteristics, such as the intelligence of a learner. It is also affected by other factors such as predispositions or behaviors towards student's environment, more especially of their attitudes towards the class.

The need to conduct this study is essential for students as the declining performance in mathematics is still present until now in both national and international assessments. Aduda (2003) mentioned that despite the vital role of mathematics in society, there has always been below-average performance in the subject not only in national examinations but also in international assessment. There are lots of factors affecting the mathematical performance of the students. However, the researcher found out that no evident studies focusing on the mediating effect of students' attitudes toward career aspirations and academic achievement of senior high school students. The researcher aims to provide essential insight to students to become aware of the vital connection between their attitude and interest towards mathematics. Moreover, as teachers and administrators seek new ways to motivate the students, this study will help them realize students' aspirations in life. This study is vital towards the success of mathematics education research, not only in the Philippines but also in all regions.

\section{Research Methods}

\section{Research design}

This study employed a descriptive - correlational design. The descriptive method is used to identify and describe the level of students' attitudes and career aspirations, 
together with their academic achievement. According to Leedy and Ormrod (2010), correlational research is concerned with establishing relationships between two or more variables in the same population or between the same variables in two populations. Correlation research employed a survey method attempted to find the mediating effect of attitude to career aspiration and academic achievement of the students in learning mathematics using questionnaires.

\section{Research setting}

This study was conducted in one of the higher educational institutions offering Senior High School in Davao Region, Philippines. This institution houses Grade 12 students who have Basic Calculus subjects. These students were from the Science and Technology, Engineering Mathematics (STEM) strand in Senior High School.

\section{Research subjects}

Due to the existence of a health crisis, convenience sampling was used in selecting the respondents of the study. For the safety and convenience of the researcher, all grade 12 students who have Basic Calculus subjects under the researcher's class were the respondents of the study. The researcher utilized a complete enumeration since there were only five sections with Basic Calculus subjects that could provide detailed information on all or most elements in the population (Australian Bureau of Statistics and McLennan, $\underline{1999}$ ). Further, according to Garibaldi (2002), complete enumeration may prefer to use in this study since there is a limited or small data population available. It is more reliable and accurate than a sample survey. The school has more than five sections, however, only these five sections have basic calculus subjects and it is under the researcher's class. There was 199 total students from these five sections, and that led the researcher to use convenience and complete enumeration samplings.

\section{Research instrument}

A survey questionnaire was utilized and distributed to all respondents. It is both adopted and the researcher-made questionnaire. One of the adopted survey questionnaires comprises 26 items about students' attitudes towards the mathematics subject of Kasimu and Imoro's (2017) study. This survey questionnaire is used to determine the attitude of the respondents towards learning mathematics. Table 1 depicts the descriptive rating and interpretation of the level of students' attitudes towards mathematics.

Table 1

Measures in determining the level of students' attitude of Grade 12 students

\begin{tabular}{ccl}
\hline Range & $\begin{array}{c}\text { Descriptive } \\
\text { Rating }\end{array}$ & Interpretation \\
\hline $4.21-5.00$ & Very high & Having a very strong level of attitude towards mathematics. \\
$3.41-4.20$ & High & Having a strong level of attitude towards mathematics. \\
$2.61-3.40$ & Moderate & Having an average level of attitude towards mathematics. \\
$1.81-2.60$ & Low & Having a weak level of attitude towards mathematics. \\
$1.0-1.80$ & Very low & Having a very weak level of attitude towards mathematics. \\
\hline
\end{tabular}

The result of the validity and reliability test of this adopted test questionnaire gave a Cronbach's alpha of 0.900 , which was considered excellent. There were no deleted test items.

Another adopted survey questionnaire is composed of 24 items from the sample questionnaire about Career Aspiration of Gregor and O'Brien (2015). This survey questionnaire is used to determine the career aspiration of the respondents towards 
learning mathematics. Table 2 depicts the descriptive rating and interpretation of the level of students' career aspirations.

Table 2

Measures in determining the level of students' career aspiration of Grade 12 students

\begin{tabular}{ccl}
\hline Range & $\begin{array}{c}\text { Descriptive } \\
\text { Rating }\end{array}$ & Interpretation \\
\hline $4.21-5.00$ & Very high & Having a very strong level of career aspiration towards mathematics. \\
$3.41-4.20$ & High & Having a strong level of career aspiration towards mathematics. \\
$2.61-3.40$ & Moderate & Having an average level of career aspiration towards mathematics. \\
$1.81-2.60$ & Low & Having a weak level of career aspiration towards mathematics. \\
$1.0-1.80$ & Very low & Having a very weak level of career aspiration towards mathematics. \\
\hline
\end{tabular}

The result of the validity and reliability test of this adopted test questionnaire gave a Cronbach's alpha of 0.950, which is considered as excellent. All of the items passed the reliability test.

Another instrument that was utilized is the researcher-made questionnaire. The content of the researcher-made test questionnaire was based on the Basic Calculus subject specifically the topic discussed by the researcher. The basis for comparing how it related to the students' career aspiration and attitude were their scores. Table 3 depicts the interpretation of the result of the researcher-made test questionnaire. Also, computer software computed the standard deviations of the variables. This tool was also to analyze the correlation of the said variables.

Table 3

Interpretation of students' academic achievement

\begin{tabular}{|c|c|c|}
\hline Range & $\begin{array}{l}\text { Descriptive } \\
\text { Rating }\end{array}$ & Interpretation \\
\hline $23.40-26$ & Very high & Having an outstanding level of academic achievement in mathematics. \\
\hline $22.10-23.39$ & High & Having a very satisfactory level of academic achievement in mathematics. \\
\hline $20.80-22.09$ & Moderate & Having a satisfactory level of academic achievement in mathematics. \\
\hline $19.50-20.79$ & Low & $\begin{array}{l}\text { Having a fairly satisfactory level of academic achievement in } \\
\text { mathematics. }\end{array}$ \\
\hline 19.50 and below & Very low & Have not met the level of expectation in learning mathematics. \\
\hline
\end{tabular}

The item analysis results stated that out of the proposed 40 - item test, 14 items were rejected, 15 items were revised, and 11 items were retained. Overall, the difficulty index (p) of the test questionnaire is 0.661, which means some of the items are easy, while the discrimination index (D) is 0.323 , which means some of the items are reasonably good.

\section{Data gathering procedure}

Before the data gathering, both the researcher-made and the adopted questionnaires have been validated by five experts in the field ( 2 mathematics teachers, a psychometrician, data analyst, and a grammarian). One of the adopted survey questionnaires comprises 26 items with four main components; anxiety, confidence, enjoyment, and benefits and value about students' attitudes towards the mathematics subject of Kasimu and Imoro (2017) study. This adopted questionnaire is a five-point response item, ranging from 1 (Strongly disagree) to 5 (Strongly agree). Another adopted survey questionnaire is composed of 24 items from the sample questionnaire about Career Aspiration of Gregor and O'Brien (2015) having a five-point response item ranging from 1 (Not all true of me) to 5 (Very true of me). Based on the validation form provided by the school which contains already the 4 main types of validity, the result was very good based on the ratings given by the experts. In addition, the adopted questionnaires have passed the reliability test and have a good 
internal consistency using the most common measure of internal consistency used by researchers, Cronbach's alpha.

The researcher asked permission through letters. First, the researcher asked the school principal to conduct pilot testing as a preliminary procedure before the conduct of the research. As mentioned earlier, the test questionnaires, both the researcher-made and the adopted questionnaires, were used to conduct pilot testing. The researcher administered the pilot test at a particular private school in Davao Region that offers a STEM strand to senior high school students since only STEM students have Basic Calculus Subject. Then, the result of the pilot test underwent reliability and validity tests administered by a data analyst. The result of the validity and reliability test of the adopted test questionnaires gave a Cronbach's alpha of 0.900 , and 0.950 , which was considered excellent. There were no deleted test items in both adopted test questionnaires.

The researcher sent another letter of permission addressed to the school principal for the study's conduct. Then, the researcher of this study used the available questionnaires regarding students' attitudes and career aspirations from the internet. The researcher ensured that they already passed the validity and reliability tests. The school principal gave the researcher one hour in each section to administer the survey and test questionnaire. The respondents were informed and given individually a questionnaire 0 answer. Answered questionnaires then had been gathered, responses had been encoded, and subjected to the appropriate statistical computations.

\section{Data analysis}

The researcher analyzed and interpreted the data using the mean, the Pearson Product Moment Correlation Coefficient, and the regression analysis. Mean was used to determine the levels of students' career aspiration, students' attitude towards the class, and their academic achievement. Pearson Product Moment Correlation Coefficient was used to determine the relationship between students' career aspirations to attitudes and academic achievement in learning mathematics. Regression Analysis was used to describe the nature of the relationship between variables (Beers, 2020) especially in determining the mediating effect of students' attitude to career aspiration and mathematics achievement. It was used to the predict values of one variable based on the values of another variable. Statistical software was employed in order to generate the result. The significant level of this study was equal to 0.05 .

This research study used the four-step approach for testing mediation by Baron and Kenny (1986) using statistical software. Using regression analysis to explain how mediation process is conducted; first conduct simple regression analysis with $\mathrm{X}$ and $\mathrm{Y}$ second, simple regression analysis with $X$ predicting $M$; third, simple regression analysis with $\mathrm{M}$ predicting $\mathrm{Y}$; and lastly, conduct a multiple regression analysis with $\mathrm{X}$ and $\mathrm{M}$ predicting.

\section{Results and Discussion}

The results are presented with descriptive statistics (means and standard deviations) for Tables 4, 5, and 6 . The correlation was also used to determine the relationship between students' career aspirations and academic achievement. The researcher utilized mediation analysis to determine the mediating effect of students' attitudes to career aspiration and mathematics achievement. 


\section{Career Aspiration}

Table 4

Mean score of students' career aspiration

\begin{tabular}{lcccc}
\hline & $\mathrm{N}$ & Mean & Std. Dev & Descriptive Rating \\
\hline Career Aspiration & 199 & 3.90 & 0.99 & High \\
\hline
\end{tabular}

Table 4 shows the level of Students Career Aspirations with 24 items sampled to 199 total number respondents. The results manifest that the mean score of students' career aspiration is 3.90 ( $\mathrm{SD}=0.99$ ), which means 'high' based on the interpretation found in Table 2. This group of respondents had described the situation that students have a 'strong' level of career aspiration towards mathematics. Thus, it manifests that most of the selected respondents find their Career Aspirations as influential. The present result indicated that the respondents who have a high interest in the subject know what they will be in the future. A particular country in Europe where students talked about the subject mathematics is highly useful and relevant to what they were doing and wanted to do in the future like being an engineering student, and these students as learners of mathematics suited their desire to become engineers (Harris et al., 2015). In addition, the result was supported by Mazana, Suero Montero, and Olifage (ㅁ19) stating that having an aspiration towards mathematics leads to an essential stepping stone when it is linked to what they are going to be in the future like in science, engineering, and business fields.

Academic Achievement

Table 5

Mean score of students' academic achievement

\begin{tabular}{ccccc}
\hline & $\mathrm{N}$ & Mean & Std. Dev & Descriptive Rating \\
\hline Academic Achievement & 199 & 21.73 & 3.65 & Moderate \\
\hline
\end{tabular}

Table 5 summarizes that the mean score of students' academic achievement is 21.73 (SD $=3.65)$, which means 'moderate' based on the interpretation found in Table 3. This group of respondents had described the situation that the student has a basic understanding of the subjects but with certain deficiencies. Even though the result is moderate, there are still students who find the subject mathematics difficult to learn. Based on the result, there are 20 more students who got below satisfactory scores than above satisfactory scores. The result supported in the study conducted by Zakaria and Salleh (2015) stated that the students find calculus difficult. Mathematics subject is one of the second most challenging areas of specialization in both primary and secondary Villaver (2014). Students must have developed the fundamental knowledge and skills to solve mathematics problems with assistance or help from their peers or teachers.

\section{Students' attitude}

Table 6 shows the descriptive analysis of students' attitudes categorized into four different indicators. The results manifest that out of all students' attitude indicators, only benefits/value with a mean of $4.02(\mathrm{SD}=0.91$ ) registers a high mean description. This group of respondents had described the situation that students have a 'strong' level of attitude towards mathematics in terms of benefits/value. They have this strong agreement towards the importance of mathematics in everyday life. It is supported in the study by Sanchal and Sharma (2017), in which most of the students felt mathematics as an essential and relevant subject in their everyday life. Thus, it manifests that the Benefits/Values Level "highly" influences students' attitudes towards academic achievement. 
Table 6

Mean score of students' attitude

\begin{tabular}{lccccl}
\hline & $\mathrm{N}$ & Mean & Std. Dev & $\begin{array}{c}\text { Descriptive } \\
\text { Rating }\end{array}$ & \multicolumn{1}{c}{ Interpretation } \\
\hline Anxiety & 199 & 3.17 & 1.14 & Moderate & $\begin{array}{l}\text { Having an average level of attitude towards } \\
\text { mathematics. }\end{array}$ \\
\hline Confidence & 199 & 2.93 & 1.01 & Moderate & $\begin{array}{l}\text { Having an average level of attitude towards } \\
\text { mathematics. }\end{array}$ \\
\hline Enjoyment & 199 & 3.24 & 0.98 & Moderate & $\begin{array}{l}\text { Having an average level of attitude towards } \\
\text { mathematics. }\end{array}$ \\
\hline Benefits/Value & 199 & 4.02 & 0.91 & High & $\begin{array}{l}\text { Having a strong level of attitude towards } \\
\text { mathematics. }\end{array}$ \\
\hline OVERALL & 199 & 3.38 & 1.00 & Moderate & $\begin{array}{l}\text { Having an average level of attitude towards } \\
\text { mathematics. }\end{array}$ \\
\hline
\end{tabular}

Furthermore, most of the indicators except benefits/value (high) register a moderate mean description. This group of respondents had described the situation that students have an average level of attitude towards mathematics in terms of anxiety, confidence, and enjoyment. It is close to the other studies where students who find enjoyment towards mathematics show positive feelings towards the subject (Zan \& Martino, 2007). High confidence makes students solve the problem and achieve comfortability in expressing ideas (Sanchal \& Sharma, 2017), and having higher mathematics anxiety tends to have low performance (Jolejole-Caube, Dumlao, \& Abocejo, 2019). Thus, it manifests that the latter mentioned indicators influence students' attitudes towards academic achievement. In the overall result, considering the four different factors of students' attitude namely anxiety, confidence, enjoyment, and benefits/values, students' attitude registered an overall mean of 3.38 ( $\mathrm{SD}=1.00$ ) which indicates that students' attitude in general "moderately" influences students' academic achievement which is somehow close to the result of the other studies in which students in mathematics is significantly related. These results agree with the study conducted by Mohamed and Waheed (2011) stating that students' positive attitude towards mathematics is at a neutral or moderate level, and there is room for improvement. Langat ( $\underline{2015}$ ) also emphasized that students' positive attitude is a way of ensuring high achievements in mathematics.

\section{Correlation between students' career aspiration and academic achievement}

Table 7

Relationship of students' career aspiration towards academic achievement of senior high school students

\begin{tabular}{lll}
\hline & & $\begin{array}{l}\text { Academic } \\
\text { Achievement }\end{array}$ \\
\hline \multirow{3}{*}{ Career Aspiration } & Pearson Correlation & .052 \\
& Sig. (2-tailed) & .462 \\
& $\mathrm{~N}$ & 199 \\
\hline
\end{tabular}

**. Correlation is significant at the 0.05 level (2-tailed).

Table 7 depicts the Pearson correlation or $r$ value is 0.052 , denoting a very weak positive correlation between career aspiration and academic achievement. The results indicated that the relationship between career aspiration and academic achievement showed a positive correlation but insignificant result.

Since the p-value of 0.462 is greater than 0.05 , the alpha level of significance, then the relationship is not significant. So, there is no significant relationship between students' career aspirations and academic achievement. Hence, the null hypothesis was failed to reject. The result is contrary to the studies conducted by Abu-Hilal (2000) and Poudel and 
Maharjan (2017) in which students with high career aspirations tend to have a higher achievement compared to those students with low career aspirations. However, the result is consistent in some cases where students' academic achievement made no significant relationship in their career aspirations (Udoukpong et al., 2012). Regardless of academic achievement, students are still highly influential to their career aspirations (Creed, Conlon \& Zimmer - Gembeck, 2007), and it does not play any role in students' career aspirations (Kainthola, 2016).

\section{Mediation analysis of the three variables}

Mediation analysis developed by Baron and Kenny (1986) is the relationship between the mediator and dependent variables when yearning for the relationship between the mediating variable and independent variable (Coulacoglou \& Saklofske, 2017). As Lapointe-Shaw et al. (2018) cited, mediator variables lie along the causal pathway between an independent and dependent variable, explaining all or part of the effect of the independent variable on the dependent variable (MacKinnon, Fairchild, \& Fritz, 2007).

Table 8

\begin{tabular}{llllll}
\multicolumn{5}{c}{ Regression results of the variables in the four criteria of the presence of mediating effect } \\
\hline Step & Path & $\begin{array}{l}\text { Beta } \\
\text { (Unstandardized) }\end{array}$ & $\begin{array}{l}\text { Standard } \\
\text { Error }\end{array}$ & $\begin{array}{l}\text { Beta } \\
\text { (Standardized) }\end{array}$ & p-value \\
\hline Step 1 & c & 1.099 & 1.487 & 0.052 & 0.462 \\
Step 2 & a & 0.139 & 0.042 & 0.228 & 0.001 \\
Step 3 & b & 1.070 & 1.531 & 0.051 & 0.486 \\
Step 4 & c' & 0.187 & 2.509 & 0.005 & 0.941 \\
\hline
\end{tabular}

There are four steps to be met for a third variable to be acting as a mediator. In Table 8, these are categorized as follows: step 1 is the relationship between the independent and dependent variables (estimate and test path c); step 2 is the relationship between the independent and mediating variable (estimate and test path a); step 3 is the relationship between the mediating and dependent variable (estimate and test path b); and lastly, step 4 is establishing that mediating variable mediates the relationship between the independent and dependent variables considering the effect of the latter relationship controlling for mediating variable (path $c^{\prime}$ ) should be equal to zero (MacKinnon et al., 2007). Path $c$ in Table 8 is called the total effect. The effect of the independent variable on the dependent variable may be mediated by a process or mediating variables, and the independent variable may still affect the dependent variable.

In step 1, career aspiration as the independent variable (IV) does not significantly predict students' academic achievement, study's dependent variable (DV). Since the pvalue of 0.462 is higher than 0.05 , the alpha level of significance, which means that the relationship is not significant. Moreover, there is no significant relationship between career aspiration (IV) and academic achievement (DV); there is nothing to mediate. Although this claim is controversial under Baron and Kenny's (1986) steps, the mediating process can still proceed since there is an excellent theoretical background between their relationship (Shrout \& Bolger, 2002).

In step 2, career aspiration significantly predicts the overall student's attitude, the mediator (M). The beta coefficient in Table 8 depicts the $p$-value of 0.001 for career aspiration, which suggests that there is a significant effect on overall students' attitudes. Explicitly, in every unit increase in career aspiration, holding other variable constant, it can also give a percentage increase of 0.139 in overall students' attitudes. The findings of the study are consistent with those of Boe and Henriksen (2015) and Regan and DeWitt (2015), which stressed that students' attitudes are especially relevant to their career 
aspirations. Fundamentally, various aspects of students' lives, such as their parents' beliefs (DeWitt et al., 2011) and classroom experiences (Wang, 2012), may influence their attitudes, which may then primarily influence their aspirations. Also, their belief in mathematics as a relevant subject can assist them in their future career (Yara, 2009).

In step 3, the overall students' attitudes do not significantly predict students' academic achievement. Table 8 depicts step 3 which has a p-value of 0.486 , which is higher than 0.05 , the alpha level of significance; then, the relationship is not significant. The findings concerning the significance between students' attitudes and academic achievements and attitudes in mathematics are consistent with research showing that mathematics performance is not significant to students' attitudes (Jaen \& Bacay, 2016; Tan \& Cordova, 2018). With these findings, this research has joined the school of thought that relates student attitude insignificantly to student performance. Nevertheless, the other studies' findings demonstrated that students' attitudes are significantly related to academic achievement (Mensah et al., 2013; Peteros et al., 2019; Tudy, 2014).

In the three steps (paths $a, b$, and $c$ ), only path $b$ is significant; this suggests that further mediation analysis will not be warranted. Based on the flowchart of mediation analysis made by Kim ( $\underline{2016})$, there is no need to go further analysis, such as full or partial mediation. In this case, the third variable, which is students' attitude, does not mediate the relationship between career aspiration and academic achievement. Their career aspiration does not directly affect academic achievement without the influence of any variable.

Figure 1 is the visual depiction of Table 8 with the regression equation of

$$
Y=78.762+1.07 x_{1}+0.187 x_{2}
$$

Standardized Coefficients

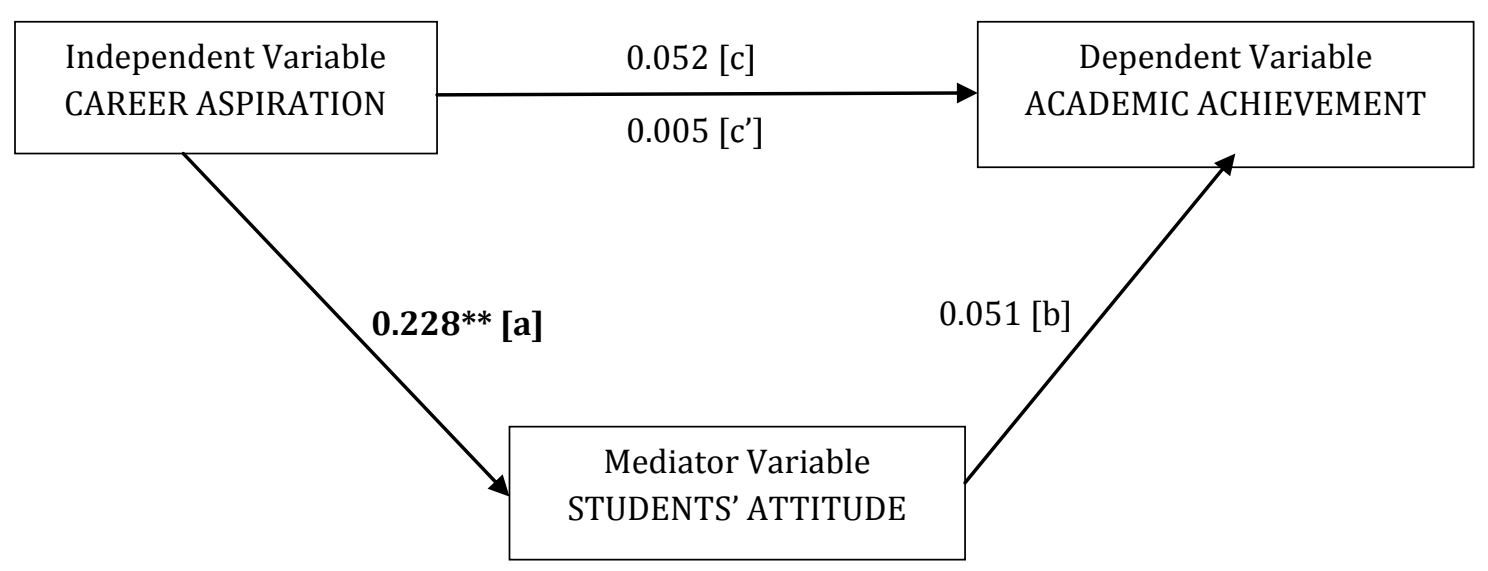

Figure 1.Visual Depiction of the Mediation analysis

The result of this study provides an understanding that students' attitude does not mediate the relationship between career aspiration and achievement of the students in learning mathematics. The mediator has nothing to do with the relationship between career aspiration and academic achievement in learning mathematics since career aspiration at the same time students' attitudes do not influence academic achievement. This is in contrast to Ajzen (1991) theory of planned behavior where students are willing to do their best or how much of an effort. They are planning to exert in learning, a particular subject that inspires them for their future and Maio et al. (2018) Multicomponent model of attitude in which student's academic achievement is also affected by other factors such as predispositions or behaviors towards their environment, more especially of their attitudes towards the class. However, career aspiration and students' 
attitudes are significantly related. Teachers should understand the dynamics between students' aspiration and their attitudes so that they can exert effort on those students who lack interest in mathematics. Their guidance in developing students' attitudes could help them realize their aspirations in life. Students can enter the classroom with a good attitude, eagerness to learn, and participate that would bring students positive energy to make learning easier for them. Provide activities that will help the students to have a considerable positive attitude in learning mathematics and will help in developing students' career aspirations.

This study intended to determine the mediating effect of students' attitudes on students' career aspirations and academic achievement in learning Mathematics. An advanced method of mediation was not adopted since this research study is not for practical purposes which required bootstrapping as compared with simple regressionbased analysis.

\section{Conclusion}

Based on the data gathered, the following conclusions were drawn: First, the overall weighted mean of the level of student's career aspiration was interpreted as "high". It implies that the students' career aspiration is at a high average level which means that students have a strong level of career aspiration towards mathematics. Thus, it suggests that respondents considered career aspiration as influential to the academic achievement of the students in mathematics. Second, the overall weighted mean of the level of students' academic achievement was interpreted as "satisfactory". It implies that the students have a satisfactory level of academic achievement in mathematics. Third, the overall weighted mean of the level of students' attitudes in mathematics was interpreted as "moderate". It implies that the students have a moderate level of attitudes which means that that the situation may or may not be manifested. Fourth, there is no significant relationship between students' career aspirations and the academic achievement of the students. Lastly, students' attitude does not mediate the relationship between career aspiration and academic achievement. Moreover, a similar study should be conducted to compare, and contrast results on the mediating effect of students' attitude to students' career aspiration and mathematics achievement since there is a minimal source found in this kind of study. Future researchers may use this as their basis and reference for future studies involving the factors that would influence the mediating effect of students' attitudes to students' career aspirations and mathematics achievement.

\section{Acknowledgment}

The researcher would like to extend the deepest gratitude to the people who supported completing the research successfully.

\section{Bibliography}

Abu-Hilal, M. M. (2000). A structural model of attitudes towards school subjects, academic aspiration and achievement. Educational Psychology, 20(1), 75-84. https://doi.org/10.1080/014434100110399

Aduda, D (2003). Kenya Certificate of Secondary Education, Examination Results Released by Minister of Education. Daily Nation, Nairobi: Nation Media Group Ltd.

Agcopra, S. A. (2009). Attitudinal factors and mathematical learning ability. ADDU-SAS Graduate School Research Journal, 5(1), 1-1. 
Archer, L., Dawson, E., DeWitt, J., Seakins, A., \& Wong, B. (2015). "Science capital": A conceptual, methodological, and empirical argument for extending bourdieusian notions of capital beyond the arts. Journal of Research in Science Teaching, 52(7), 922948. https://doi.org/10.1002/tea.21227

Australian Bureau of Statistics (ABS) \& McLennan, W. (1999). An Introduction to Sample Surveys: A User's Guide. Australian Bureau of Statistics (ABS).

Ajzen, Icek (1991). The theory of planned behavior. Organizational Behavior and Human Decision Processes. 50 (2), 179-211. https://doi.org/10.1016/0749-5978(91)90020$\underline{T}$

Ballado-Tan, J. (2014). Academic performance, aspirations, attitudes and study habits as determinants of the performance in licensure examination of accountancy graduates. International Journal of Education and Research, 2(12), 61-70.

Baron, R. M., \& Kenny, D. A. (1986). The moderator-mediator variable distinction in social psychological research: Conceptual, strategic, and statistical considerations. Journal of Personality and Social Psychology, 5, 1173-1182. https://doi.org/10.1037//00223514.51.6.1173

Beers, B. (2020). What Regression Measures. Retrieved from https://www.investopedia.com/terms/r/regression.asp

Bøe M.V., \& Henriksen E.K. (2015) Expectancy-value perspectives on choice of science and technology education in late-modern societies. In Henriksen E., Dillon J., Ryder J. (eds) Understanding Student Participation and Choice in Science and Technology Education. Springer, Dordrecht. https://doi.org/10.1007/978-94-007-7793-4 2

Bohner, G., \& Dickel, N. (2011). Attitudes and attitude change. Annual Review of Psychology, 62(1), 391-417. https://doi:10.1146/annurev.psych.121208.131609

Casinillo, L. F., \& Aure, M. R. K. L. (2018). Econometric Evidence on Academic Performance in Basic Calculus of Science, Technology, Engineering and Mathematics (STEM) Senior High Students. Journal of Educational and Human Resource Development, 6, 238-249.

Coulacoglou, C., \& Saklofske, D. H. (t). Validity. Psychometrics and Psychological Assessment, 45-66. https://doi.org/10.1016/b978-0-12-802219-1.00003-1

Creed, P. A., Conlon, E. G., \& Zimmer-Gembeck, M. J. (2007). Career barriers and reading ability as correlates of career aspirations and expectations of parents and their $\begin{array}{llll}\text { children. Journal of Vocational } & 242\end{array}$ 258. https://doi.org/10.1016/j.jvb.2006.11.001

Cuy, N. A., \& Salinas, E. M. (2019). Aspiration and Readiness of Filipino Senior High School Students in Pursuing College Degree. Open Journal of Social Sciences, 7(05), 143. https://doi.org/10.4236/jss.2019.75012

Department of Education. (2018). DepEd, DOST ink pact to further Science, Math education of teachers, learners. Retrieved from https://www.deped.gov.ph/2018/08/16/depeddost-ink-pact-to-further-science-math-education-of-teachers-learners/

Department of Education. (2018). Implementing Guidelines on the Conduct of Remedial and Advancement Classes During Summer for the $K$ to 12 Basic Education Program. Retrieved from $\quad$ https://www.deped.gov.ph/2018/03/23/do-13-s-2018implementing-guidelines-on-the-conduct-of-remedial-and-advancement-classesduring-summer-for-the-k-to-12-basic-education-program/

Dela Cruz, M. (2017). Science education and a thinking society. Retrieved from https://opinion.inquirer.net/102324/science-ed-thinking-society

DeWitt, J., Archer, L., Osborne, J., Dillon, J., Willis, B., \& Wong, B. (2011). High aspirations but low progression: The science aspirations-careers paradox amongst minority ethnic 
students. International Journal of Science and Mathematics Education, 9(2), 243271.https://doi.org/10.1007/s10763-010-9245-0

Dwivedi, V. (2012). Relationship between level of aspiration and achievement in social sciences. International Journal of Research in Engineering, IT and Social Sciences (IJREISS), 2(2), 61-66.

Eagly, A. H., \& Chaiken, S. (1993). The psychology of attitudes. Harcourt brace Jovanovich college publishers.

Edokpayi, J. N., \& Suleiman, M. A. (2011). Students integrated science achievement as a predictor of later achievement in chemistry: A case study among selected secondary schools in Zaria metropolis. Archives of applied Science Research, 3 (4), 527-535.

Garibaldi, L. (2002). Note on FAO activities related to fishery statistical development. Proceedings of the FAO/SEAFDEC Regional Training Workshop on the Use of Statistics and Other Information for Stock Assessment. Retrieved from http://www.fao.org/3/ac831e/ac831e05.htm\#bm5.1.2

Gorard, S., See, B. H., \& Davies, P. (2012). The impact of attitudes and aspirations on educational attainment and participation. Retrieved from https://www.researchgate.net/publication/265288552 The Impact of Attitudes an d Aspirations on Educational Attainment and Participation

Gravemeijer, K., Stephan, M., Julie, C., Lin, F. L., \& Ohtani, M. (2017). What mathematics education may prepare students for the society of the future?.International Journal of Science and Mathematics Education, 15(1), 105-123. https://doi.org/10.1007/s10763-017-9814-6

Gregor, M. A., \& O’Brien, K. M. (2015). Understanding Career Aspirations Among Young Women: Improving Instrumentation The Journal of Career Assessment. https://doi.org/10.1177/1069072715599537

Harris, D., Black, L., Hernandez-Martinez, P., Pepin, B., Williams, J., \& with the TransMathsTeam. (2015). Mathematics and its value for engineering students: what are the implications for teaching? International Journal of Mathematical Education in Science and Technology, 46(3), 321-336. https://doi.org/10.1080/0020739X.2014.979893

Ingram, N. (2015). Students' relationships with mathematics: Affect and identity. Mathematics Education Research Group of Australasia.

Jaen, M. C. A., \& Baccay, E. S. (2016). Curiosity, motivation, attitude, gender, and mathematics performance. The Normal Lights, 10(2), 89-103.

Jolejole-Caube, C., Dumlao, A. B., \& Abocejo, F. T. (2019). Anxiety towards mathematics and mathematics performance of grade 7 learners. European Journal of Education Studies. https://doi.org/10.5281/zenodo.2694050

Kainthola, R. (2016). Academic achievement and occupational aspiration of secondary level students in relation to their self-esteem and socio-economic status. (Unpublished doctoral dissertation). Kumaun University, Nainital

Kasimu, O., \& Imoro, M. (2017). Students" attitudes towards mathematics: the case of private and public Junior High Schools in the East Mamprusi District, Ghana. IOSR Journal of Research \& Method in Education (IOSR-JRME), 7(5), 38-43. https://doi.org/10.9790/7388-0705063843

Khattab, N. (2015). Students' aspirations, expectations and school achievement: What really matters?.British Educational Research Journal,41(5), 31-748. https://doi.org/10.1002/berj.3171 
Kim, B. (2016). Introduction to mediation analysis. University of Virginia Library Research Data Services + Sciences. Retrieved from https://data.library.virginia.edu/introduction-to-mediation-analysis/

Lapointe-Shaw, L., Bouck, Z., Howell, N. A., Lange, T., Orchanian-Cheff, A., Austin, P. C., ... \& Bell, C. M. (2018). Mediation analysis with a time-to-event outcome: a review of use and reporting in healthcare research. BMC medical research methodology, 18(1), 1-12. https://doi:10.1186/s12874-018-0578-7

Langoban, M. (2020). What Makes Mathematics Difficult as a Subject for most Students inHigher Education? International Journal of English and Education,9(3), 214-220.

Langat, A. C. (2015). Students' attitudes and their effects on learning and achievement in Mathematics: A Case study of public secondary schools in Kiambu County, Kenya. Unpublished a Research Project, submitted in partial fulfilment of the requirements for the Degree of Master of Education of Kenyatta University.

Leedy, P. D., \& Ormrod, J. E. (2010). Practical research (Vol. 108). Saddle River, NJ: Pearson Custom.

MacKinnon, D. P., Fairchild, A. J., \& Fritz, M. S. (2007). Mediation Analysis. Annual Review of Psychology, 58(1), 593-614. https://doi.org/:10.1146/annurev.psych.58.110405.085542

Maio, G. R., Haddock, G., \& Verplanken, B. (2018). The psychology of attitudes and attitude change. Sage Publication.

Mazana, Y. M., Suero Montero, C., \& Olifage, C. R. (2019). Investigating students' attitude towards learning mathematics. International Electronic Journal of Mathematics Education, 14 (1), 207-231. https://doi.org/10.29333/iejme/3997.

Mensah, J. K., Okyere, M., \& Kuranchie, A. (2013). Student attitude towards mathematics and performance: Does the teacher attitude matter. Journal of Education and Practice, $4(3), 132-139$.

Mohamed, L., \& Waheed, H. (2011). Secondary students' attitude towards mathematics in a selected school of Maldives. International Journal of humanities and social science, 1(15), 277-281.

Mujtaba, T., Sheldrake, R., Reiss, M. J., \& Simon, S. (2018). Students' science attitudes, beliefs, and context: associations with science and chemistry aspirations. International Journal of Science Education,40(6), 644-667. https://doi.org/10.1080/09500693.2018.1433896

Mullis, I. V. S., Martin, M. O., Goh, S., \& Cotter, K. (Eds.) (2016). TIMSS 2015 Encyclopedia: Education Policy and Curriculum in Mathematics and Science. Retrieved from Boston College, TIMSS \& PIRLS International Study Center. Retrieved from http://timssandpirls.bc.edu/timss2015/encyclopedia/

Mutai, J. K. (2011). Attitudes towards learning and performance in mathematics among students in selected secondary schools in Bureti district, Kenya. [Master's Thesis, Kenyatta University]. Kenyatta University Institutional Repository. https://irlibrary.ku.ac.ke/handle/123456789/334

National Research Council. (2013). The mathematical sciences in 2025. National Academies Press.

Narad, A., \& Abdullah, B. (2016). Academic performance of senior secondary school students: Influence of parental encouragement and school environment. Rupkatha Journal on Interdisciplinary Studies in Humanities Special Issue,3(2), 12-19. http://dx.doi.org/10.21659/rupkatha.v8n2.02 
Ndirangu, C. W., Nyagah, G. M., \& Kimani, G. N. (2017). The level of implementation of ASEI/PDSI classroom practices in science subjects: A case of SMASSE project, Kenya. International Journal of Learning, Teaching and Educational Research, 16(5).

Nicolas, C. A. T., \& Emata, C. Y. (2018). An integrative approach through reading comprehension to enhance problem solving skills of grade 7 mathematics students. International Journal of Innovation in Science and Mathematics Education (formerly CAL-laborate International), 26(3).

Peteros, E., Columna, D., Etcuban, J. O., Almerino Jr, P., \& Almerino, J. G. (2019). Attitude and academic achievement of high school students in mathematics under the conditional cash transfer program.International Electronic Journal of Mathematics Education, 14(3), 583-597. https://doi.org/10.29333/iejme/5770

Poudel, T. N., \& Maharjan, R. K. (2017). Association between the level of aspiration and achievement of students of secondary Level.Journal of Advanced Academic Research, 4(2), 55-67. https://doi.org/10.3126/jaar.v4i2.19535

Rabgay, T. (2015). A study of factors influencing students' academic performance in a Higher secondary school in Bhutan. Rabsel-the CERD Educational Journal, 16.

Regan, E., \& DeWitt, J. (2014). Attitudes, interest and factors influencing STEM enrolment behaviour: An overview of relevant literature. Understanding Student Participation

and Choice in Science and Technology Education, 63-88. https://doi.org/10.1007/978-94-007-7793-4 5

Sanchal, A., \& Sharma, S. (2017). Students' attitudes towards learning mathematics: Impact of teaching in a sporting context. Teachers and Curriculum, 17 (1), $\quad$ 89-99. https://doi.org/10.15663/tandc.v17i1.151

Scheibelhofer, E. (2017). Shifting migration aspirations in second modernity. Journal of Ethnic and Migration Studies, 44(6), 999-1014. https://doi.org/10.1080/1369183X.2017.1384151

Schleicher, A. (2019). PISA 2018: Insights and Interpretations. OECD Publishing.

Shrout, P. E., \& Bolger, N. (2002). Mediation in experimental and non experimental studies: new procedures and recommendations. Psychological Methods, 7, 422-445.

Tan, D. A. \& Cordova, C. (2018). Mathematics Proficiency, Attitude and Performance of Grade 9 Students in Private High School in Bukidnon, Philippines\|. Asian Academic Research Journal of Social Sciences and Humanities, 5(2), 103-116.

The Manila Times (2014). Passions run low for math, science. Retreived from https://www.manilatimes.net/2014/02/10/news/national/passions-run-low-formath-science/74629/

Tudy, R. A. (2014). Attitude, self-efficacy and students' academic performance inmathematics. IAMURE International Journal of Social Sciences. http://doi.org/10.7718/ijss. v12i1, 920.

Udoukpong, B. E., Emah, I. E., \& Umoren, S. E. (2012). Student attitudes, parental influence and career aspirations in academic achievement in entrepreneurial curriculum. Academic Research International, 2(1), 527.

Villaver, L. (2014). Experiential Learning Approach, Effects on the Mathematics Performance and Attitude. [Master's Thesis, Central Mindanao University].

Wang, M. T. (2012). Educational and career interests in math: A longitudinal examination of the links between classroom environment, motivational beliefs, and interest. Developmental psychology, 48(6), 1643. https://doi.org/10.1037/a0027247

Yara, P. (2009). Students attitude towards mathematics and academic achievement insome selected secondary schools in Southwestern Nigeria. European Journal of Scientific Research. 36. 336-341. 
Zakaria, E., \& Salleh, T. S. (2015). Using Technology in Learning Integral Calculus. Mediterranean Journal of Social 144. https://doi:10.5901/mjss.2015.v6n5s1p144

Zan, R. and Martino, P. D. (2007). Attitudes toward Mathematics: Overcoming positive/negative dichotomy. The Montana Mathematics Enthusiasts Monograph, 3, 157-168.

Ziegler, G. M., \& Loos, A. (2017). "What is Mathematics?" and why we should ask, where one should experience and learn that, and how to teach it. In Proceedings of the 13th International Congress on Mathematical Education (pp. 63-77). Springer, Cham. https://doi.org/10.1007/978-3-319-62597-35 